\title{
Bimbingan Pembuatan dan Penggunaan Alat Peraga Permainan Olahraga Tradisional Bagi Guru SDN 95 Bontobulaeng Kecamatan Bulukumpa Kabupaten Bulukumba
}

\author{
Lutfi $^{1}$, Andi Makkasau ${ }^{2}$, Nasaruddin ${ }^{3}$ \\ ${ }^{1,2,3}$ Pendidikan Guru Sekolah Dasar, Fakultas Ilmu Pendidikan, Universitas Negeri Makassar \\ 1lutfi.b@unm.ac.id \\ 2andi.makkasau@unm.ac.id \\ 3nasaruddin@unm.ac.id
}

\begin{abstract}
ABSTRAK
Permasalahan sekolah mitra adalah terbatasnya media pembelajaran yang kini digunakan, baik kuantitas maupun kualitasnya Pengabdian masyarakat bertujuan untuk (1) mempergunakan Alat Peraga Permainan Olahraga Tradisiona, Seni dan IPA dalam melaksanakan pembelajaran sesuai materi yang diajarkan untuk meningkatkan efesiensi waktu dalam proses pembelajaran, (2) meningkatkan kemapuan penguasaan materi dan keterampilan menggunakan alat peraga Permainan Olahraga Tradisiona, Seni dan IPA bagi Guru-guru di SDN 95 Bontobulaeng Kecamatan Bulukumpa Kabupaten Bulukumba. Selain itu dapat pula meningkatkan motivasi dalam proses belajar mengajar dan untuk menunjang pelaksanaan cara belajar siswa aktif (CBSA). Target khusus yang ingin dicapai adalah (1) menambah pengetahuan dan keterampilan serta kreatifitas guru menggunakan alat praktik alat peraga dalam percobaan, (2) mengembangkan media pembelajaran berdasarkan kebutuhan belajar dan perkembangan anak, serta (3) teratasinya kesulitan/keterbatasan penggunaan alat peraga Permainan Olahraga Tradisional, Seni dan IPA dalam percobaan untuk keperluan pembelajaran. Metode dan pendekatan yang digunakan yaitu: metode ceramah bervariasi demonstrasi, dan pemberian tugas dengan penerapan pendekatan Keterampilan Proses. Metode pengabdian ini menggunakan metode seminar dan pelatihan. Hasil pengabdian ini adalah guru mampu membuat Alat peraga Permainan Olahraga Tradisional, alat perga IPA, dan alat peraga Seni rupa SD. Implikasi pengabdian ini adalah sebagai acuan oleh praktisi pendidikan untuk meningkatkan keterampilan guru dalam mengembangkan permainan tradisional yang terintegrasi dalam pembelajaran di SD.
\end{abstract}

Kata kunci: pembuatan, penggunaan, alat peraga permainan tradisional

\section{ABSTRACT}

The problem of partner schools is the limited learning media currently used, both in quantity and quality. Community service aims to (1) use traditional sports game aids, arts and science in carrying out learning according to the material being taught to increase the efficiency of time in the learning process, (2) improve the mastery of the mastery of the material and skills using teaching aids Traditional Sports Games, Art and Science for Teachers at SDN 95 Bontobulaeng Bulukumpa District Bulukumba Regency. Besides that it can also increase motivation in the teaching and learning process and to support the implementation of active student learning (CBSA). Specific targets to be achieved are (1) increasing the knowledge and skills as well as the creativity of teachers using teaching aids in experimentation tools, (2) developing learning media based on children's learning and development needs, and (3) addressing the difficulties / limitations of using Sports Games teaching aids Traditional, Arts and Natural Sciences in experiments for learning purposes. The method and approach used are: lecture method varies demonstration, and assignment of tasks by applying the Process Skills approach. This service method uses seminar and training methods. The result of this dedication is that the teacher is able to make teaching aids for traditional sports games, science equipment, and visual art aids. The implication of this service is as a reference by educational practitioners to improve teacher skills in developing traditional games that are integrated in learning in elementary schools..

Keywords: making, using, traditional game props 


\section{PENDAHULUAN}

Proses Belajar Mengajar (PBM) dengan menggunakan alat bantu pembelajaran yang tepat adalah salah satu metode yang diharapkan dapat mempercepat penguasaan pengetahuan dan keterampilan terhadap materi yang dipelajarinya (Aip Syarifuddin, 1993). Anak usia sekolah dasar memiliki kemampuan sangat terbatas dalam mentransfer ilmu pengetahuan dan keterampilan yang dipelajarinya sehingga perlu dibantu melalui berbagai cara/metode pendekatan pembelajaran, terutama program pendekatan yang menekankan pada pengembangan kemampuan untuk meningkatkan pengetahuan dan keterampilan belajar anak pada mata pelajaran Permainan Olah raga Tradisional, Seni dan IPA.

Permainan olah raga tradisional, seni dan IPA merupakan sarana berpikir deduktif dalam menemukan dan mengembangkan ilmu pengetahuan dan teknologi, yang memungkinkan kita melakukan pengukuran secara kuantitatif. Sifat kuantitatif telah dapat meningkatkan daya prediksi dan control dari keterampilan dan ilmu pengetahuan. Dengan ilmu pengetahuan dapat memberikan jawaban yang bersifat eksak sehingga memungkinkan pemecahan masalah secara lebih tepat, cepat dan cermat.

Logika yang berpangkal dari pengetahuan, selain merupakan dasar dan pangkal tolak penemuan dan pengembangan ilmu-ilmu lain, juga telah merupakan landasan yang kuat bagi pengembangan ilmu pengetahuan dan teknologi dalam usaha meningkatkan kesejahteraan umat manusia. Oleh karena itu, Permainan olah raga tradisional, seni dan ilmu pengetahuan alam tidak lagi dipandang hanya sebagai ilmu pengetahuan tetapi lebih dari itu, telah menjadi sarana untuk menjadi hakikat keilmuan, sehingga tidak dapat disangkal lagi bahwa untuk menunjang keberhasilan penguasaan ilmu pengetahuan dan teknologi peranan permainan olahraga tradisional, seni dan ilmu pengetahuan alam menjadi sangat dominan.

Penguasaan permainan olahraga tradisional, seni dan IPA secara umum yang didukung oleh penguasaan terhadap konsep, alat peraga permainan olahraga tradisional, seni dan IPA di sekolah dasar akan memberikan landasan yang kuat untuk menguasai dan mengembangkan ilmu pengetauan dan teknologi, sedang penguasaan konsep permainan olahraga tradisional di sekolah menengah akan sangat ditentukan oleh penguasaan anak didik terhadap konsep mata pelajaran yang ada di sekolah dasar.

Sebagai diketahui bahwa siswa sekolah dasar masih pada taraf berpikir. Oleh karena itu diperlukan suatu media/alat peraga yang dapat menghubungkan taraf berfikir yang dimiliki siswa SD. Salah satu media tersebut adalah alat peraga permainan olahraga tradisional, seni dan IPA.

Peningkatan kualitas sumber daya manusia, menuntut penguasaan konsep dasar permainan olahraga tradisional, seni dan IPA bagi anak didik di sekolah dasar perlu disempurnakan dan ditingkatkan. Demikian pula alat peraga permainan olahraga tradisiona, seni dan alat peraga IPA yang memang sudah dirancang khusus sesuai tujuannya yang ada di sekolah tersebut jarang digunakan karena pengetahuan dan kemampuan guru untuk itu sangat terbatas. Salah satu pendekatan yang digunakan ialah penyajian materi melalui penggunaan alat peraga permainan olahraga tradisional, seni dan IPA di sekolah dasar.

Pembelajaran permainan olahraga tradisional, seni dan IPA yang baik memang tidak cukup hanya bersumber pada buku. Pembelajaran itu harus dilengkapi dengan alat praktik berupa alat peraga yang sesuai dengan mata pelajaran permainan olahraga tradisional, seni dan IPA yaitu alat-alat yang digunakan untuk demonstrasi atau praktek permainan olahraga tradisional/ praktikum IPA. Di Sekolah dasar yang dapat dihubungkan dengan lingkungan alam dapat mendorong anak untuk mengembangkan dasar-dasar pengetahuan, ketrampilan, kemampuan dan sikap yang berguna untuk melanjutkan studi maupun hidup dalam masyarakat.

Sehubungan dengan hal tersebut di atas, maka pengabdian pada masyarakat difokuskan pada Sekolah Dasar dalam memberikan penyuluhan kepada guru dan bimbingan kepada murid untuk berbagi pengalaman, pengetahuan, dan keterampilan dalam melaksanakan praktek/percobaan dengan menggunakan peralatan alat peraga permainan olahraga tradisional, seni dan IPA Sekolah Dasar.

Berdasarkan wawancara pengabdi dengan guru-guru di sekolah mitra Ada tiga kondisi utama yang sering dialami guru di kelas yakni: (1) guru mengalami kesulitan menggunakan alat peraga permainan olahraga tradisional, seni dan IPA dalam melaksanakan pembelajaran sesuai dengan pokok bahasan yang tersedia, (2) guru kurang mampu 
membuat alat peraga permainan olahraga tradisional, seni dan IPA sederhana, dan (3) guru kurang terampil dalam membimbing siswa membuat alat peraga permainan olahraga tradisional, seni dan IPA.

Melihat pentingnya penggunaan alat peraga dalam menunjang kegiatan pembelajaran. Maka kegiatan pengabdian ini bertujuan untuk (1) mempergunakan Alat Peraga Permainan Olahraga Tradisiona, Seni dan IPA dalam melaksanakan pembelajaran sesuai materi yang diajarkan untuk meningkatkan efesiensi waktu dalam proses pembelajaran, (2) meningkatkan kemapuan penguasaan materi dan keterampilan menggunakan alat peraga Permainan Olahraga Tradisiona, Seni dan IPA bagi Guru-guru di SDN 95 Bontobulaeng Kecamatan Bulukumpa Kabupaten Bulukumba. Selain itu dapat pula meningkatkan motivasi dalam proses belajar mengajar dan untuk menunjang pelaksanaan cara belajar siswa aktif (CBSA). Target khusus yang ingin dicapai adalah (1) menambah pengetahuan dan keterampilan serta kreatifitas guru menggunakan alat praktik alat peraga dalam percobaan, (2) mengembangkan media pembelajaran berdasarkan kebutuhan belajar dan perkembangan anak, serta (3) teratasinya kesulitan/keterbatasan penggunaan alat peraga Permainan Olahraga Tradisional, Seni dan IPA dalam percobaan untuk keperluan pembelajaran.

\section{METODE KEGIATAN}

Peserta pengabdian ini adalah guru SDN 95 Bontobulaeng Kecamatan Bulukumpa Kabupaten Bulukumba sebanyak 15 orang. Metode pelaksanaanya yaitu dengan menggunakan metode seminar dan pelatihan. Adapun penjelasanya sebagai berikut:

1. Seminar mengenai penggunaan alat peraga

Pada PKM ini diberikan seminar kepada guru SD. Seminar ini bertujuan untuk memberikan informasi kepada guru SD mengenai pentingnya penggunaan alat peraga.

Luaran kegiatan ini adalah meningkatnya pengetahuan dan pemahaman guru mengenai penggunaan alat peraga dalam pembelajaran.

2. Pelatihan pembuatan alat peraga

Pada tahap ini guru dilatih untuk membuat alat peraga. Pada kegiatan ini guru dibekali cara untuk membuat alat peraga permainan olahraga tradisionnal dan IPA serta melaksanakan pembelajaran sesuai materi yang diajarkan untuk meningkatkan efesiensi waktu dalam proses pembelajaran

Luaran kegiatan ini adalah produk alat peraga yang telah dikembangkan dan digunakan dalam mengajar di kelas.

Untuk mengukur keberhasilan PKM ini maka dilakukan evaluasi berupa penilaian pemahaman konsep dan penilaian keterampilan. Pengabdian dikatakan berhasil jika guru memiliki peningkatan dalam pemahaman konsep serta mendapatkan skor rata diatas 75 dan mendapatkan skor diatas 75 untuk setiap rata-rata indikator dalam pembuatan dan penggunaan alat peraga.

\section{HASIL \& PEMBAHASAN}

Pelaksanaan kegiatan ini terbagi menjadi dua bagian pokok yaitu :

1. Seminar mengenai penggunaan alat peraga Kegiatan seminar ini merupakan kegiatan pemberian materi dari pengabdi ke mitra. Materi yang disampaikan tentang tata cara pembuatan dan penggunaan alat peraga permainan olahraga trdisional dan IPA SD kepada Guru. Kemudian dilanjutkan dengan tanya jawab. Kegiatan seminar ini diikuti para guru dengan sangat antusias. Hal ini ditunjukkan dengan banyaknya pertanyaan dari para guru terkait pembuatan dan efektifitas penggunaan alat peraga yang nantinya akan dikembangkan.

2. Pelatihan pembuatan alat peraga

Kegiatan pembuatan alat peraga merupakan kegiatan lanjutan setelah seminar dilakukan. Hal ini dilakukan untuk merefleksikan kegiatan seminar yang telah dilakukan. Pada kegiatan ini guru-guru diajak untuk membuat beberapa alat peraga dan praktek menggunakannya diantaranya :

a. Alat peraga olahraga tradisional
1) Engrang Batok Kelapa
2) Bakiak
3) Dham-dhaman
4) Platokan
5) Lompat Karet

b. Alat Peraga Percobaan IPA

1) Penjernihan Air

2) Percobaan kincir air sederhana

3) Percobaan kaleng menari

4) Percobaan air mendaki

5) Roket air Sederhana

c. Alat Peraga Seni
1) Mozaik
2) Montase
3) Talenan hias
4) Lukisan 
Saat seminar berlangsung, diperoleh gambaran bahwa guru sangat membutuhkan alat bantu permainan olahraga tradisional, seni dan IPA guna mengatasi kesulitan yang selama ini dihadapi. Penjelasan dalam bentuk seminar, memberikan respon yang sangat positif dari guru yang ditandai dengan timbulnya keaktifan guru memberikan kegiatan atau aktivitas seputar penggunaan alat peraga permainan olahraga tradisional SD. Ini menunjukkan bahwa seorang guru perlu dibekali dengan pengetahuan dan keterampilan dalam bentuk penggunaan peralatan untuk meningkatkan kualitas sumber daya manusia yang dimiliki khususnya menyangkut penggunaan dan pembuatan alat peraga dalam pembelajaran.

Pada kegiatan demonstrasi penggunaan alat peraga, menunjukkan bahwa menggunaan alat peraga permainan olahraga tradisonal dan IPA di SDN 95 Bontobulaeng Kabupaten Bulukumba belum maksimal karena di temukan beberapa kendala dalam penggunaan alat peraga. hal ini ini terjadi karena banyaknya langkah kerja dari setiap percobaan belum dipahami dengan baik, dengan demikian pendampingan dalam penggunaan alat peraga terus dilakukan sampai guru mahir menggunakan alat peraga yang telah dibuat supaya nantinya bisa diajarkan kepada siswanya.

Kegiatan pendampingan memberikan dampak positif kepada guru dengan hampir semua guru telah mengetahui pentingnya pelaksanaan praktek/ percobaan dengan menggunakan alat peraga dalam pembelajaran permainn olahraga tradisional dan IPA. Melalui pemahaman akan pentingnya alat peraga membuat para guru terbebas dari rutinitas pencapaian target kurikulum yang kaku. Yang lebih dipentingkan ialah materi pelajaran telah selesai semua disajikan. Akibatnya, siswa lebih banyak diam, pasif, tidak lebih dari mendengarkan dan menyalin serta memperaktekan hanya yang diketahui oleh guru saja.

Sebenarnya guru dapat saja melaksanakan pembelajaran dengan menggunakan alat peraga pada setiap pembelajaran permainan olahraga tradisional, seni dan IPA di kelas. Alat peraga permainan olahraga tradisional, seni dan IPA SD meskipun belum lengkap telah tersedia dan alat serta bahan untuk penggunaan alat peraga dapat saja dirakit sendiri oleh guru. Demikian pula kulaifikasi pendidikan guru cukup mendukung karena mereka kebanyakan telah selesai pendidikan S1.

Respon guru terhadap kegiatan pengabdian pembuatan dan penggunaan alat peraga permainan olahraga tradisional, seni dan IPA di SDN 95 Bontobulaeng Kabupaten Bulukumba dapat dilihat pada tabel 1 dibawah ini.

Tabel 1. Respon Guru terhadap kegiatan pengabdian pembuatan dan penggunaan alat

\begin{tabular}{|c|c|c|c|}
\hline No. & Sikap guru & Setuju & $\begin{array}{l}\text { Tidak } \\
\text { Setuju }\end{array}$ \\
\hline 1. & $\begin{array}{l}\text { Guru akan } \\
\text { membuat alat } \\
\text { peraga permainan } \\
\text { olahraga } \\
\text { tradisional, seni } \\
\text { dan IPA } \\
\text { Sederhana seperti } \\
\text { yang dilatihkan }\end{array}$ & $\sqrt{ }$ & \\
\hline 2. & $\begin{array}{l}\text { Guru tertarik } \\
\text { membuat } \\
\text { rancangan alat } \\
\text { peraga yang lain } \\
\text { sesuai meteri } \\
\text { permainan } \\
\text { olahraga } \\
\text { tradisional dan } \\
\text { IPA }\end{array}$ & & $\sqrt{ }$ \\
\hline 3. & $\begin{array}{l}\text { Alat Peraga } \\
\text { permainan } \\
\text { olahraga } \\
\text { tradisional, seni } \\
\text { dan IPA efektif } \\
\text { digunakan dalam } \\
\text { pembelajaran }\end{array}$ & $\sqrt{ }$ & \\
\hline 4. & $\begin{array}{l}\text { Alat Peraga } \\
\text { permainan } \\
\text { olahraga } \\
\text { tradisional, seni } \\
\text { dan IPA praktis } \\
\text { digunakan dalam } \\
\text { pembelajaran. }\end{array}$ & $\sqrt{ }$ & \\
\hline 5. & $\begin{array}{l}\text { Guru permainan } \\
\text { olahraga } \\
\text { tradisional, seni } \\
\text { dan IPA tertarik } \\
\text { menggunakan } \\
\text { alat peraga } \\
\text { tersebut dalam } \\
\text { pembelajaran }\end{array}$ & $\sqrt{ }$ & \\
\hline 6. & $\begin{array}{l}\text { Jika alat Peraga } \\
\text { permainan } \\
\text { olahrag } \\
\text { tradisional dan } \\
\text { IPA mengalami } \\
\text { kerusakan } \\
\text { mestinya Guru } \\
\text { bersedia } \\
\text { memperbaiki atau }\end{array}$ & & $\sqrt{ }$ \\
\hline
\end{tabular}




\begin{tabular}{|c|c|c|}
\hline & menggantinya. & \\
\hline 7. & $\begin{array}{l}\text { Jika Alat Peraga } \\
\text { permainan } \\
\text { olahraga } \\
\text { tradisional, seni } \\
\text { dan IPA sudah } \\
\text { rusak total } \\
\text { sebagai seorang } \\
\text { Guru perlu } \\
\text { membuat alat } \\
\text { sederhana yang } \\
\text { mirip dengan } \\
\text { aslinya }\end{array}$ & $\sqrt{ }$ \\
\hline 8. & $\begin{array}{l}\text { Guru seharusnya } \\
\text { membuat alat } \\
\text { peraga permainan } \\
\text { olahraga } \\
\text { tradisional, seni } \\
\text { dan IPA yang } \\
\text { lain yang tidak } \\
\text { tersedia di } \\
\text { sekolah }\end{array}$ & $\sqrt{ }$ \\
\hline 9. & $\begin{array}{l}\text { Penggunaan Alat } \\
\text { Peraga permainan } \\
\text { olahraga } \\
\text { tradisional, seni } \\
\text { dan IPA SD perlu } \\
\text { tetap } \\
\text { dipertahankan } \\
\text { pengunaannya } \\
\text { jika sesuai } \\
\text { dengan } \\
\text { karakteristik anak } \\
\text { usia SD. }\end{array}$ & $\sqrt{ }$ \\
\hline 10. & $\begin{array}{l}\text { Guru termotivasi } \\
\text { mengajar bila } \\
\text { menggunakan } \\
\text { alat peraga } \\
\text { permainan } \\
\text { olahraga } \\
\text { tradisional dan } \\
\text { IPA }\end{array}$ & $\sqrt{ }$ \\
\hline 11. & $\begin{array}{l}\text { Guru perlu } \\
\text { dilatih tentang } \\
\text { Pembuatan dan } \\
\text { Penggunaan Alat } \\
\text { Peraga permainan } \\
\text { olahraga } \\
\text { Tradisional dan } \\
\text { IPA }\end{array}$ & $\sqrt{ }$ \\
\hline 12. & $\begin{array}{l}\text { Guru masih } \\
\text { membutuhkan } \\
\text { penyuluhan dan }\end{array}$ & $\sqrt{ }$ \\
\hline
\end{tabular}

\begin{tabular}{|l|l|l|}
\hline bimbingan & \\
tentang & & \\
pembuatan dan & & \\
penggunaan Alat & & \\
Peraga permainan & \\
olahraga & & \\
tradisional dan & & \\
IPA & & \\
\hline
\end{tabular}

Kegiatan pelaksanaan atau ketercapaian pelaksanaan praktek/ praktikum bagi murid diperoleh hasil sbb: 16,67 \% dengan kategori sangat baik, 33,33\% kategori baik, 29,17\% kategori cukup, dan hanya 20,83 $\%$ dengan kategori kurang.

Melalui demonstrasi penggunaan alat peraga dalam proses belajar mengajar Permainan olahraga Tradisional dan IPA, guru dapat merangsang munculnya motivasi dalam diri siswa. Motivasi itu akan semakin kuat apabila guru dan siswa sama-sama menggunakan alat peraga dalam pembelajaran.

Selanjutnya motivasi yang kuat akan memberikan hasil belajar yang optimal. Jadi dapat ditegaskan bahwa dengan adanya alat peraga dalam pembelajaran Permainan Tradisional dan IPA, akan memberikan hasil belajar yang lebih baik.

Pengabdian ini membuktikan bahwa guru sekolah dasar telah mampu membuat dan menggunakan alat peraga dengan baik. Hal ini disebabkan selama pengabdian berlangsung guru mengikuti kegaiatan dengan aktif sehingga tujuan pengabdian tercapai dengan baik. Keaktifan guru selama mengikuti pelatihan akan berpengaruh terhadap ketercapaian pelatihan (Rahmawati, 2014; Dewi \& Suhardini, 2014).

Keaktifan guru membuktikan bahwa guru memiliki motivasi yang tinggi untuk melaksanakan pelatihan. Motivasi tersebut berdampak terhadap ketercapaian tujuan pembelajaran (Fenia, 2018). Hal ini lah yang mempegaruhi keberhasilan dalam pengabdian ini.
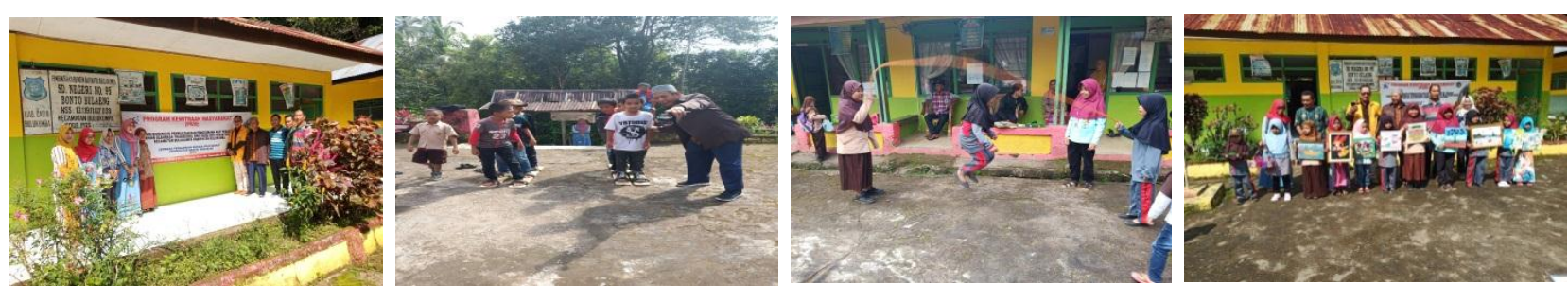

Gambar 1 Foto Kegiatan Pengabdian 


\section{KESIMPULAN \& SARAN}

Berdasarkan hasil dan pembahasan kegiatan pembuatan dan penggunaan Alat Peraga permainan olahraga tradisional dan IPA, dapat disimpulkan sbb:

a. Guru olahraga, seni dan IPA perlu dibekali dengan pengetahuan dan keterampilan membuat dan menggunakan peralatan alat peraga permainan olahraga tradisional, seni dan IPA yang dirakit untuk dapat meningkatkan kualitas guru-guru di Sekolah Dasar.

b. Sikap Guru terhadap pembuatan alat peraga olahraga, seni dan IPA tentang pembuatan dan penggunaan alat peraga tersebut di SDN 95 Bontobulaeng Kabupaten Bulukumba sangat positif yang ditandai dengan banyaknya pernyataan sikap setuju terhadap pembuatan dan penggunaan alat peraga permainan olahraga tradisional, seni dan IPA yang diisikan pada lembar Observasi tentang pembuatan dan penggunaan alat peraga permainan olahraga tradisional, seni dan IPA yang di amati ternyata hanya dua komponen yang dinyatakan tidak setuju $(16,67 \%)$ dari 12 komponen yang diamati. ini berarti lebih banyak komponen yang disikapi setuju.

Saran dari pengabdian ini adalah agar guru selalu melatih kemapuan membuat dan menggunakan alat peraga agar dapat meningkatkan keterampilan dan kualitas pembelajaran.

\section{DAFTAR PUSTAKA}

Aip Syarifuddin, 1993:Pendidikan Jasmani dan Kesehatan. Depdikbud, Jakarta.

Akbar Sutawidjaya, 1995: Penggunaan Alat Peraga Dalam Pengajaran. Suatu penelitian Rangkuman. Puslit IKIP Malang.

Carin, A.A. and Sund, R.B., Teaching Modern Science, Charles E. Merril Co., A Bell \& Howell Company, London, 1985.

Chalik Toho, 1997:Pendidikan jasmani dan kesehatan, Depdikbud, Jakarta.

Dewi, L., \& Suhardini, A. D. (2014). Peningkatan kompetensi pedagogik guru melalui pelatihan paikem (pelatihan pada guru MI dan MTS di Kabupaten Cianjur). Edutech, 13(1), 409-419.

Dian Kristiani, 2015:Ensiklopedia Negeriku Permainan Tradional, Penerbit PT. Bhuana Ilmu Populer, Jakarta.

Fenia, S. Z. (2018). Pengaruh Motivasi Kerja, Pelatihan Dosen Dan Komitmen
Organisasi Terhadap Kinerja Dosen Pada Sekolah Tinggi X Di Sumatera Barat. Jurnal Benefita: Ekonomi Pembangunan, Manajemen Bisnis dan Akuntansi, 3(1), 76-83.

Harlen, W. Teaching and Learning Primary Science, Harper \& Row Publishers, London, 1985.

Harre, R., The Philosophies of Science, Oxford University Press, Oxford, 1985.

Harsuki, 2003:Perkembangan Olahraga Terkini, Penerbit PT Rajagrafindo persada, Jakarta.

Herman Hudoyo, 1990. Strategi Belajar Mengajar. Penerbit IKIP Malang.

Husna M, 2009:Permaian Tradisional Indonesia, Penerbit Andi, Yogyakarta.

Suko Riyanto, 1990. Pengaruh Alat Peraga Sebagai Alat Bantu Dalam Pengajaran. FPMIPA IKIP Malang.

Sri Mulyani, 2013.45 Permainan Tradisional Indonesia. Pernerbit Langensari Publishing. Yogyakarta

Unesco, Unesco Handbook for Science Teachers, Unesco Paris, 1980. 